\title{
THE IMPACT OF CANCEL CULTURE ON KAROL CONKÁ CAREER
}

O IMPACTO DO CANCELAMENTO NA CARREIRA DA KAROL CONKÁ

\section{Carolina Guarieiro}

Graduação em Comunicação Social - Publicidade e Propaganda pela Universidade de Brasilia (Brasília/Brasil).

E-mail: contatocarolinaguarieiro@gmail.com

\section{Marlise Viegas Brenol}

Doutora em Comunicação e Informação pelo Programa de Pós-Graduação em Comunicação da Universidade Federal do Rio

Grande do Sul (Porto Alegre/Brasil). Professora voluntária na Universidade de Brasília (Brasilia/Brasil).

E-mail: marlisebrenol@gmail.com 


\section{Brazilian

\section{ABSTRACT}

This paper analyzes the impact of the cancel culture on Karol Conká's career after participating at brazilian's TV Globo show called Big Brother Brasil in 2021. Conká was invited to participate as a celebrity and social media influencer to join the reality show and compete for the money prize with non-celebrities. Considering the visibility that the program provides to participants and audience, the research proposes a case study on the transgressions that caused the cancellation of the artist during the period of confinement in the house and the strategies used to reconstruct her public image. This work at Social Communication main field of studies aimed to reference as theoretical concepts digital social media, visibility and digital influencers, to trace a path to the functioning of social networks dynamics. Karol Conká is a justified case study because she was eliminated with the highest rejection rate at Big Brother Brother's history. The conflicts she was involved in during the show resulted in a loss of thousands followers on Instagram and brought important consequences for her career. As a result, the case study shows that the strategy of silence followed by mental balance narrative was well succeeded to recover audience empathy.

Keywords: Cancel Culture. Social Communication. Public Image.

\section{RESUMO}

Este artigo analisa o impacto da cultura do cancelamento na carreira da artista Karol Conká após participar do programa brasileiro da TV Globo chamado Big Brother Brasil, em 2021. Conká foi convidada a participar do reality show como celebridade e influenciadora digital para competir pelo prêmio em dinheiro com não celebridades. Considerando a visibilidade que o programa proporciona aos participantes, a pesquisa realizou um estudo de caso sobre as transgressões que ocasionaram o cancelamento da artista durante o período de confinamento na casa e as estratégias utilizadas para reconstruir sua imagem pública. Este trabalho, na área de estudos da Comunicação Social, utilizou como embasamento os conceitos de mídias sociais digitais, visibilidade e de influenciadores digitais, para traçar o impacto negativo provocado pela audiência nas redes sociais. A escolha do caso se justifica porque Karol Conká foi eliminada com o maior índice de rejeição da história do Big Brother Brasil. Os conflitos durante o show resultaram na perda de milhares de seguidores no perfil do Instagram e importantes consequências para sua carreira. Como resultado, o estudo de caso apontou que a estratégia de silenciamento, seguida da narrativa de equilíbrio emocional e saúde mental, foi bem sucedida para recuperar a empatia da audiência.

Palavras-chave: Cultura do Cancelamento. Comunicação Social. Imagem Pública. 


\section{Brazilian

\section{INTRODUCTION}

Karol Conká, rapper and artist, was the protagonist of one of the most representative episodes of the cancel culture in Brazil. Artist, black and woman, Karol had in February the highest rejection rate in the history of the reality show Big Brother Brasil (BBB), produced and broadcast by Rede Globo television, the biggest media conglomerate in South America. It is the audience that votes to decide which participants might leave and which might stay in the house each week. Globo is the leading open television channel in terms of audience in the country (IBOPE MEDIA, 2021). The visibility of entertainment TV shows like the $B B B$ is both desired to boost careers and feared when the effect is reversed.

As we show in this article, Karol suffered from the feared effect. The artist's attitudes in the BBB's house provoked hatred and rejection in the audience. The demonstrations spread across social media platforms in an orchestrated attack against Karol official profiles. There was even the creation of a profile against the singer at Instagram with a number of followers higher than the official one. The singer's marketing team even froze publications to contain the loss of followers, which reached 300,000 less people on Instagram in a short period.

Considering the emblematic episode, this article presents an analysis of the impact of cancellation on Karol Conká's career. The methodology adopted was a case study, using exploratory research, documentary research, and analysis of media products. The objectives outlined were to identify the milestones that led to her cancellation, analyze the audience's reactions on social media and reconstruct the marketing team's strategy to recover the singer's public image.

This article is divided into an introduction and four more parts. The first one presents the theoretical concepts, considering studies about cancellation culture, social media, visibility and public image. The next part justifies the case study's choice as a methodology, including the explanation of research instruments. In the analysis and discussion we present the study itself and the analysis results. In the final part, considerations are made about the theme pointing to future studies.

\section{LITERATURE REVIEW}

Within digital social media evolution, new and potential personal interaction networks emerged. According to Aimola (2010), digital social media outlets are online technologies used by people to disseminate content, whether personal or informative, opinions, experiences and ideas, thus becoming a set of collaborative and interactive media. The popularization of digital social media outlets brought with it the possibility of following, sharing and commenting on absolutely any topic. According to Lemos 


\section{Brazilian \\ Creative Industries}

and Lévy (2000), the internet as a media ambience supports more than information and interaction, it is an environment where all users easily interact with one another, whether they are well known as public figures or not. According to Santaella (2003), around the 1990s, the term media was specifically linked to the mass communication media, referring to the outlets of information and entertainment, such as newspapers, magazines, radio and television. In addition, the term media also came to designate all the media in which advertising circulates. Santaella also explains that the term has become more and more popular "by the rubric of "media" to the point that any medium of social communication currently receives the generic name of "media" and their set of outputs." (authors translation, SANTAELLA, 2004, p. 76).

Recuero (2011) explains that access to information has become more democratic and that social media have revolutionized interpersonal relationships. Social media sites were especially significant for the digital revolution because they enable networks that are permanently connected and ubiquitous. The internet social media is the space in which information circulates synchronously (as in conversations, for example) and asynchronously (as in sending messages on leaving a content published to be read at any time). Recuero (2012) defines that social networks have become the place in which information circulates, is filtered and shared in personal networks.

People are logged and connected to conversation, which may be a debate, discussion and potentially new forms of social organization based on collective interests. As messages are sent to the individual's network, some people will receive it when they connect, as it will remain stored. Thus, messages constructed by one individual at any network can have massive reach and imparable impact.

Mafra (2018, p. 49) explains that there is today a "public visibility space" mediated by mediatization where a subject has to become visible in order to exist. According to Sgorla (2010, p. 04) the visibility processed in the media outlets is generally massive, and is considered a "species of reference for social existence, so much that some scholars even defend the extreme expression that "what exists is what is in the media" (author's translation).

Sgorla (2010) also explains that the content which becomes visible in the media is not characterized by spontaneity, quite the contrary, there is image treatment and manipulation involving composition strategies about what is intended to be shown or hidden. In this regard, we can highlight the television editions made in reality shows such as Big Brother Brasil where there is a short 15, 30 or 60 minutes compact edition about all content recorded 24 hours a day. The short edition is broadcasted at TV show time delimiting what will gain greater or lesser visibility.

Sometimes the narrative on television may provoke a reaction from TV viewers and online audiences. NG (2020) analyses one of the first episodes known as cancel culture in the United States. The television series "The 100" in 2016 was outraged by the death of a lesbian character, killed off just after she and 


\section{Brazilian \\ Creative Industries}

another female character had made love for the first time. The showrunner Jason Rothenberg, who had by that time amassed 120,000 followers on Twitter, lost 14,000 of them in the 24 hours after the death episode. As NG explains, it was "an act of what has come to be termed as cancel culture" and also define it as

\footnotetext{
"the withdrawal of any kind of support (viewership, social media follows, purchases of products endorsed by the person, etc.) for those who are certified to have said or done something unacceptable or highly problematic, generally from a social justice perspective especially alert to sexism, heterosexism, homophobia, racism, bullying, and related issues." (NG, 2020, p. 623).
}

The cancel culture also reaches less known people, not only celebrities. A podcast from NPR called "The Callout" profiled an American musician called Emily and stated that she rejected a band colleague, who was her best friend, when he was accused of sending a sexual nude picture to another woman. Emily's public image was associated with believing and supporting women. But a few months later, Emily itself was cancelled because of an old bullying record from high school. Emily case, as David Brooks (2019) calls cruelty, refers to the ideological purity and the loss of a reasonable scale of transgression within culture. As authors claim, culture most often involves previously silenced groups intending to outrage the power of those traditionally privileged by gender, race, and so on.

\section{METHODOLOGY}

As a methodology strategy, we chose the case study as guidance to analyse in depth the object Karol Conká as her cancellation impact. Yin (2015) explains that the case study is an investigative survey of current phenomena in contemporary contexts. Gil (1991) explains that the method is characterized by an exhaustive and in-depth research of few objects of study.

For a better construction of the research, a qualitative approach was taken to understand and describe the Cancel Culture and its means of action - social media networks. Gil (1991) classified the research, regarding the object of study, in three categories: exploratory, explanatory and descriptive. For this research, the three methods were implemented, exploratory research addressed discussion of concepts about culture of cancellation, a current phenomenon that has been little studied considering specific aspects of it, also situating as core concepts studies on social media and visibility. Then, we followed a descriptive research about Karol Conká's career and her participation in the reality show, thus 


\section{Brazilian

arriving at an explanatory research approach where we identified the factors that contributed to the artist's cancellation.

Marconi and Lakatos (2017, p. 107) explains that: "the specification of the research methodology is the one that covers the greatest number of items, as it answers, at the same time, the questions what?, where?, when?, how". Thus, research is based on studying a specific subject and analyzing in depth all its aspects. Yin (2015) explains that the case study is useful as it investigates new concepts and explores their application to elements of a theory. Therefore, the case study as a method was justified because we found few studies on cancel culture in Brazil, so we aim to contribute with an in-depth empiric analysis of the topic.

\section{KAROL CONKÁ AT BBB: ANALYSIS AND DISCUSSION}

Karoline dos Santos de Oliveira, born in Curitiba-PR, on January 1, 1986, is nationally known by her artistic name "Karol Conká", which came about due to her father's influence. He advised her to always say that her name was written with a $K$ and not with a C, thus creating the artistic middle name "Conká". Karol began a career at age 17 as a rapper, prior to that, the singer had participated in dance and singing competitions at her hometown.

In 2011, Karol released his first EP entitled "PROMO", in partnership with several artists. The singer released her first album - "Batuk Freak" in 2013, which was a great success carried by the hit "Boa noite", soundtrack for the FIFA 14 game. Also in 2013, Karol won her first statuette prize at Globo's Multishow channel as an artist revelation. After the release of her hit "Tombei " in 2015, Karol returned to the Multishow Award, winning the "New Music" category. The song became the opening theme of a TV show on Globo television. In addition, Karol participated in the opening of the 2016 Olympic Games and in 2017 had her hit "Bate a Poeira" as the opening theme of the 25th edition of a popular soap opera called "Malhação - Viva a Diferença".

In 2018, Rolling Stone Brasil Magazine elected Karol Conká's album "Ambulante" the 34th best Brazilian album, and one of the 25 best albums by Associação Paulista de Críticas de Arte. At Rock In Rio 2019, Karol presented the single "Alavancou" and, in 2020, the release of a new single "Tempos Insanos".

Karoline at this stage of her career was already a celebrity and a digital influencer in social media with thousands of fans in Brazil. Silva and Tessarolo (2016) explain that the term "digital influencer" refers to people who have the power to mobilize a large number of followers, guiding behavior, opinions and creating exclusive content. Such power to persuade and become an influencer is measured by tools and metrics available on social networks and regularly turns into sponsorships. Silva and Tessarolo explain 


\section{Brazilian \\ Creative Industries}

that the digital influencer market is changing advertising investment strategies " by exerting enough force to influence the new generation to prefer a certain brand or choose a certain product equal to the one they are using, guiding a large part of young people's purchasing decisions." (authors'translation, SILVA; TESSAROLO, 2016, p. 6).

Karol entered into partnerships with large companies throughout her career, such as Caixa Econômica Federal and Nestlé, in addition to partnerships with nationally known artists. In 2021, Karol Conká was invited to join the TV show Big Brother Brasil at TV Globo as a celebrity guest. Since 2002, Rede Globo has broadcasted Big Brother Brasil, a franchising format created by Endemol media company. The TV show has a duration of two to three months. During the period, the reality show has activities and dynamics in which participants compete with each other for the $\mathrm{R} \$ 1.5$ million prize and for the audience's preference. Participants are exposed to tests and are confined, without communication with the outside world, and each week one of them is eliminated by popular vote.

The possibility of interaction with Big Brother, through the weekly elimination votes of participants, creates in the audience a feeling of power and control over the program and its participants' future. Potentially, this interactive tool can be appropriated by audience segments as an instrument to reinforce their values and desires (CAMPANELLA, 2005).

The analysis of Karol's participation and consequent cancellation was made through a case analysis, which is a qualitative method. As follows, we systematize the milestones of her performance at the TV show highlighting conflicts with other participants which ended up with cancellation by audience, then we highlight the strategies adopted by the marketing team to manage the aftermaths and finally we describe the actions to reconstruct her public image after highly negative visibility.

\subsection{MILESTONES AT BBB: THE FALL}

Karol Conká was announced as a member of the BBB 2021 casting on January 19th. The post in which the singer celebrated her entry into the TV show said "Hello, hello, Brazil! I'm confirmed. Who's ready to live all the time with all the versions of "mamacita" in the most watched house in Brazil?" (ERNANI, 2021). The program was inaugurated a few days later, on January 25th. But Karol got involved in controversies in the first week which made the singer plummet in social media followers. Only at Instagram account, Karol went from 1.8 million to 1.4 million fans, a $22 \%$ drop (NSC, 2021). The rapper resisted almost a month in the house, but on the fourth popular voting process she was eliminated with a rate of $99.17 \%$, the highest rejection record in the program's history (GSHOW, 2021).

The celebration post described before was deleted by the marketing team as well as other posts that were targeted by hate replies, comments and offenses. The decision to review and delete some posts 


\section{Brazilian \\ Creative Industries}

was made by her marketing team, which managed her public image in social media during her cancellation process and dealt with aftermaths.

\subsection{MARKETING STRATEGY: AFTERMATHS}

The cancellation wave was triggered when Karol started to have conflicts with other participants, including the actress Carla Diaz, show-winner Juliette, and the actor and singer Lucas Penteado. The case study of conflicts was based on the documentary entitled "A vida depois do tombo", produced by TV Globo. Rede Globo gave her important support to deal with the aftermath of cancellation. Directed by Patrícia Carvalho and Patrícia Cupello, the film crew accompanied Karol for a month right after leaving BBB.

The film narrates Karol and her marketing team evaluation of her performance and its consequences. During the period represented in the documentary Karol recalls the conflict with Lucas Penteado, a participant who was an ally of Karol. The disagreements begin after a party in which Lucas suggests that the black participants should form a group to compete with the white participants. Karol rejected such an idea and the artist's attitudes from that moment on became harsh towards Lucas. She even stated that she would psychologically torture the participant. In addition to the conflicts with Lucas, the artist was criticized on social media for her mocking attitude towards the accent and quirks of another participant the prize-winner Juliette, Karol even said that she was more polite than Juliette for being born in Curitiba (south region of Brazil) while she was from Northeast.

Such attitudes provoked rejection by different kinds of internet users, Karol Conká was even criticized by great and very popular artists and public figures such as Marilia Mendonça, Neymar, Bruna Marquezine, among others, which contributed to increase its cancellation effect, considering that these artists have thousand of fans and followers and are great in influencing public opinion.

The documentary is also interesting to analyse the marketing strategy facing cancellation. Karol's marketing advisers were interviewed as well. They discussed how she should behave in public and with the media and suggested that she should be sincere about her mental imbalance during the TV show, as a way to justify her attitudes and sensitize fans.

In the second episode of "A Vida Depois do Tombo", Karol questions her executive producer, Caio Piovesan, about the fact that her social networks, especially Instagram, have stopped publishing during her confinement - they also deleted some posts. Caio explains that the feedback from her followers was negative, all new posts had negative repercussions, so they decided to adopt a silence strategy during the in house conflicts. 


\section{Brazilian \\ Creative Industries}

\subsection{REBUILDING A CAREER: TALENT AND NARRATIVES}

To analyse the strategy to rebuild Karol's career, we focused on systematizing how the artist communicated with her fans after the TV Show. We identified an extension after the program: the production of the aforementioned documentary, the show presentation at the last day of the program, media interviews carried out and new musics released by Karol.

With its premiere on April 29, 2021, the documentary "A Vida Depois do Tombo" (GLOBOPLAY. 2021) was intended to show the resumption of Karol Conká after participating in Big Brother Brasil. With four episodes, the series visits the artist's past to justify her behaviors. Karol is also confronted with her actions on the TV show and has the opportunity to explain her most controversial atitudes. It also provides information on how the artist's career was affected by the cancellation, as well as the loss of followers and the strategies used by her team to reduce the negative impacts generated.

In the grand finale of Big Brother Brasil 21, Karol was one of the artists invited to sing, Karol presented her new song entitled "Dilúvio" which was written in 2020 but suffered a change in the lyrics after her participation in the program. Karol said "I wrote Diluvio last year, and it went through some changes after the experiences I had. I allowed myself to feel, I looked inside and turned all that feeling into art", explains the singer in the documentary.

In August, six months after the program, Karol was interviewed at "Altas Horas" TV show at TV Globo. She apologized for her attitude during the BBB 21 show. She confessed that she was shocked when she realized people's reaction on social media, particularly in relation to racist offences. Karol also spoke about the emotional imbalance in the house and her decision to preserve herself in order to regain confidence and move on with her career (GSHOW, 2021b).

The documentary, news songs and her participation in interviews with the mental health narrative were the beginning of a reconciliation with her fans. The new songs were also released on YouTube, where, before the reality show, she had 271,000 followers on the platform and rose to 281,000 . The numbers also rose on her instagram, Karol managed to recover the 300,000 lost followers and reached about 1.6 million followers on the social media network.

\subsection{ANALYSIS}

Recuero (2009) explains that one of the values associated with social networks is visibility, as well as the way in which the authors build and maintain network symbolic capital. Considering the visibility generated through television, especially what Big Brother Brazil provides to the participants, it is interesting to think that artists accept such experience in order to generate more visibility for their work. On the other 


\section{Brazilian \\ Creative Industries}

hand, when visibility is not positive, as in the case of Karol Conká, it is necessary to reduce posts and visibility in moments of controversy, an action carried out by her team. The strategy of reducing posts to avoid more visibility on Karol's social networks is consistent with what Recuero (2009) explains about visibility power to potentialize social values representation, where the actors interacting in a network become more visible as they contribute to social conversation. As NG (2020) agreed, cancellation happens when a public figure exposes something unacceptable for the social network, negative reaction emerges from some values from a social perspective, especially sexism, racism, bullying and related.

In interviews carried out after leaving the BBB, Karol Conká acknowledged her mistakes and expressed regret for her actions. The singer moved on with her work, regained followers and has been positioning herself on the digital interaction platform Instagram as a sensitive woman searching for emotional balance. During 2021, Karol has released four songs, namely: "Dilúvio", "Mal Nenhum", "Subida", and "Louca e Sagaz". In addition, Karol Conká launched a new video program on Instagram's IGTV where she interviews people on "Vem K" about issues regarding reflections on mental health.

\section{CONCLUSION}

In fact, Karol Conká's career was affected by the cancel culture effect. The contemporary phenomena also impacted her mental balance, a topic that Karol decided to address in her social networks after cancellation. Also in her hit "Dilúvio", the artist sings about mental balance and about following her path even on days of struggle. The artist managed to hit more than 5 million views on the music video at launch on her YouTube channel. Besides that, Karol, who strategically decided to distance herself from social media after cancellation, returned with posts about media interviews, her work, news releases and her support for social causes.

Cancellation usually involves social themes related to minorities, like sexism, racism and gender issues. In this case, the biggest conflict that triggered the cancellation was between two blacks individuals, Lucas and Karol. But it was not only the racial conflict on the agenda at BBB, but also the arrogant and prejudiced posture Karol had in relation to other participants, triggering a domino effect of prejudice.

Karol as a black woman may have potentialized her cancellation, considering that the society in which we live in is still and unfortunately very racist and sexist. Karol Conká, as a singer, has always encouraged the struggle of black women in society, the lyrics of her songs reinforce the cause and fight prejudice. It is evident that there were incoherent facts between causes defended throughout her career and her attitudes during the TV show. 


\section{Brazilian \\ Creative Industries}

Analyzing Karol Conkás trajectory and the impacts that its visibility in BBB TV show generated for her public image, it is reasonable to assume the strategy adopted by the artist's team was the best possible given the cancellation scenario. It is due to the fact that the more Karol was seen and commented, the more hate messages were addressed against her on social media. After a silent period, she gradually came back on stage emphasizing her qualities and talents, releasing relevant music and content to reconcile with fans.

This case study is a contribution to comprehension of a contemporary phenomena called cancel culture, which is closely related to the functioning of digital social media and to changings in course on the field of social communication. It is also important to advance in the understanding of studies related to gender and race to problematize whether cancellation can be linked to social and historical inequalities in Brazil.

\section{REFERENCES}

AIMOLA, Veridiana N. Empresas que criam as próprias redes de relacionamento. In: LAS CASAS, Alexandre L (Org). Marketing Interativo: A utilização de Ferramentas Digitais. São Paulo: Saint Paul Editora, 2010.

BROOKS, David. "The Cruelty of Call-Out Culture." New York Times, January 14, 2019. Available in: https:// www.nytimes.com/2019/01/14/opinion/call-out-social-justice.html. Access on: 05 Jul. 2021.

CAMPANELLA, Bruno. Entendendo o Big Brother Brasil: a recepção de um novo paradigma da televisão brasileira. Rio de Janeiro: Universidade Federal do Rio de Janeiro - Escola de Comunicação, 2005. (Projeto de tese de Doutorado).

ERNANI, Felipe. Karol Conká é confirmada como participante do BBB 21. TMDQA. 19 de janeiro, 2021. Available in: https://www.tenhomaisdiscosqueamigos.com/2021/01/19/karol-conka-big-brother-bbb/. Access on: 19 Apr. 2021.

GIL, Antonio Carlos. Como elaborar projetos de pesquisa. 3. ed. São Paulo: Editora Atlas, 1991.

GLOBOPLAY. A Vida depois do Tombo. Direção: Patrícia Carvalho e Patrícia Cupello. Documentário, 2021. Available in: https://globoplay.globo.com/a-vida-depois-do-tombo/. Access on: 14 Oct. 2021.

GSHOW. Relembre a saída de Karol Conká do BBB21. July, 13, 2021a. Available in: https://gshow.globo. com/realities/bbb/noticia/relembre-a-saida-de-karol-conka-do-bbb21.ghtml. Access on: 08 Sep. 2021. 


\section{Brazilian \\ Creative Industries}

GSHOW. Karol Conká fala sobre cancelamento e diz que é bem tratada nas ruas: 'As pessoas pedem desculpas pelas ofensas.' August, 29, 2021b. Available in: https://gshow.globo.com/programas/altas-horas/noticia/karol-conka-fala-sobre-cancelamento-e-diz-que-e-bem-tratada-nas-ruas-as-pessoas-pedem-desculpas-pelas-ofensas.ghtml. Access on: 08 Oct. 2021.

IBOPE MEDIA, Kantar. Audiência diária no horário nobre. Resultado online. November, 19, 2021. Available in: https://www.kantaribopemedia.com/audiencia-do-horario-nobre-15-mercados-08-11-a-14-11-2021/. Access on: 20 Nov. 2021.

LEMOS, André; LÉVY, Pierre. 0 futuro da internet: em direção a uma ciberdemocracia planetária. São Paulo: Paulus, 2010.

MAFRA, Rennan. Entre o espetáculo, a festa e a argumentação: mídia, comunicação estratégica e mobilização social. Belo Horizonte: Autêntica. 2018.

MARCONI, Marina; LAKATOS, Eva. Técnicas de Pesquisa. São Paulo: Editora Atlas S.A., 2007.

NG, Eve. No Grand Pronouncements Here...: Reflections on Cancel Culture and Digital Media Participation. Television \& New Media, 21(6), 621-627, 2020. Doi:10.1177/1527476420918828.

NSC. BBB 21: Lumena e Karol Conká despencam em número de seguidores nas redes sociais. February, 5. 2021. Available in: https://www.nsctotal.com.br/noticias/bbb-21-lumena-e-karol-conka-despencam-em-numero-de-seguidores-nas-redes-sociais. Access on: 21 Jun. 2021.

RECUERO, Raquel. A rede é a mensagem: Efeitos da Difusão de Informações nos Sites de Rede Social. Lo que Mcluhan no previó. 1. ed. Buenos Aires: Editorial La Crujía, 2012.

SANTAELLA, L. Da cultura das mídias à cibercultura: o advento do pós-humano. Revista Famecos, Porto Alegre, n. 22, p. 23-32, dez. 2003.

SANTAELLA, L. Navegar no ciberespaço: o perfil cognitivo do leitor imersivo. São Paulo: Paulus, 2004.

SGORLA, Fabiane. A "visibilidade midiática"da "sociedade midiática" à "sociedade midiatizada". Revista Tecer, v. 3, n. 4, p. 1-10, 2010. Doi: http://dx. doi. org/10.15601/1983-7631/rt. v3n4p1-10.

SILVA, Cristiane Rubim Manzina da; TESSAROLO, Felipe Maciel. Influenciadores digitais e as redes sociais enquanto plataformas de mídia. In: CONGRESSO BRASILEIRO DE CIÊNCIAS DA COMUNICAÇÃO, 39., 2016, São Paulo. Anais [...]. São Paulo: Intercom - Sociedade Brasileira de Estudos Interdisciplinares da Comunicação, 2016.

YIN, Robert K. Estudo de Caso: Planejamento e métodos. Bookman editora, 2015. 